\title{
Vegetation relevés and soil measurements in the Netherlands: the Ecological Conditions Database (EC)
}

\author{
G.W. Wieger Wamelink, Marjolein H.C. van Adrichem, Han F. van Dobben, Joep Y. \\ Frissel, Merel den Held, Veronique Joosten, Agnieszka H. Malinowska, Pieter A. Slim \& \\ Ruut M.A. Wegman
}

\begin{abstract}
Since its establishment around 1990, the Ecological Conditions Database (EC; GIVD ID EU-00-006) has been accumulating vegetation relevés from the Netherlands, each accompanied by at least one abiotic soil measurement (e.g. pH or nutrient availability). On 1-1-2010, the database contained 8,229 relevés, covering the period from 1936 to 2009, and representing contributions from 110 authors. The most frequently measured soil parameter is $\mathrm{pH}$, with well over 5,000 entries. All the data in the database are subjected to ISO 9001 quality control. The database can be used as the starting point for estimating plant species responses to a range of abiotic variables, such as $\mathrm{pH}$, groundwater table, or nitrate concentration, and for vegetation modelling (model parameterisation and validation).
\end{abstract}

Keywords: abiotic variable; indicator plant; nutrient; $\mathrm{pH}$, soil property; species response.

Received: 26 March 2010 - Accepted: 9 February 2011 - Co-ordinating Editor: Jörg Ewald.

\section{Introduction}

Databases of plant species occurrence in conjunction with environmental measurements can be a powerful tool in understanding ecological relations or predicting the effect of external drivers on ecological processes and species reactions (Ewald 2001, Chytrý \& Rafajová 2003, Smart et al. 2003, Schaminée et al. 2009). In this article we describe the database of plant species observations and joint abiotic measurements initially set up to cover the Netherlands. The EC Database contains a growing number of data. We are actively searching for new data to add to the EC Database including data from outside the Netherlands. The present paper will focus on the subset of data that originates form the Netherlands.

The Ecological Conditions Database (EC) was set up around 1990, initially with data used to calibrate average Ellenberg indicator values (Ellenberg et al. 1991) against measurements: thus acidity value $(\mathrm{R})$ was converted into soil $\mathrm{pH}$, moisture value $(\mathrm{F})$ into groundwater table, and nutrient value $(\mathrm{N})$ into nitrogen con- tent of the soil or biomass (see Ertsen et al. 1998, Wamelink et al. 2002). We therefore amassed vegetation relevés with at least one measured soil parameter. After having fulfilled its purpose, the initial database containing about 1,000 vegetation relevés with measured soil data remained more or less dormant until the end of the millennium, although data input continued at a low rate. After 2000 it became increasingly apparent that the use of Ellenberg's indicator values has some disadvantages (Schaffers \& Sýkora 2000, Wamelink et al. 2002, Wamelink \& van Dobben 2003a, Wamelink et al. 2005) and calls were made for an indicator system for plant species based directly on measurements instead of on expert knowledge (Wamelink et al. 2002, Witte \& von Asmuth 2003, Wamelink et al. 2003b, Smart \& Scott 2004, Wamelink et al. 2004). The EC Database then provided the starting point for an indicator system for a range of measured abiotic variables, such as $\mathrm{pH}$, groundwater table, nitrate concentration, phosphorus concentration, total nitrogen content, or chloride content.
Nowadays, the EC Database, which has grown to almost 9,000 relevés, is used not only to ascertain the responses of plant species to soil parameters, but also to estimate the ecological ranges of vegetation in various typologies, such as habitat directive types or phytosociological types (plant species associations). The data are also used for soil-vegetation modelling (for model parameterisation and validation, see e.g. Mol-Dijkstra et al. 2009, Wamelink et al. 2009).

\section{Technical description}

The EC Database consists of two separate databases: one for the soil measurements and one for the vegetation relevés. The measurements, including metadata information, are stored in a Microsoft Excel file that contains columns for the relevé ID, geographic coordinates and more than 25 abiotic soil parameters (for the most important ones, see Table 1). 


\section{Ecological Conditions Database (EC)}

Scope: The EC database is used to ascertain the responses of plant species to soil parameters and to estimate the ecological ranges of vegetation in various typologies, such as habitat directive types or phytosociological types (plant species associations). The database is contains only Dutch data, however currently being we are expanding to include European data as well, to make it applicable out The data are also used for soil vegetation modelling (for model parameterisation and validation)

Status: ongoing capture

Period: $1936-2010$

Database manager(s): Wieger Wamelink (wieger.wamelink@wur.nl); Joep Frissel (joep.frissel@wur.nl)

Owner: Alterra Wageningen UR

Web address: http://abiotic.wur.nl

Availability: free upon request

Online upload: no

Online search: no

Database format(s): MS Access, Excel

Export format(s): [NA]

Publication: Wamelink, G.W.W., Joosten, V., Dobben, H.F. van \& Berendse, F. (2002): Validity of Ellenberg indicator values judged from physicochemical field measurements. - Journal of Vegetation Science 13: 269-278.

Plot type(s): normal plots; time series

Non-overlapping plots: 8,130

Plot-size range: $1-900 \mathrm{~m}^{2}$

Total plot observations: 8,229

Estimate of existing plots: 25,000

Completeness: $33 \%$

Countries: NL: $100.0 \%$

Number of sources: 91

Valid taxa: 1,752

Forest: $[\mathrm{NA}]$ - Non-forest: [NA]

Guilds: all vascular plants: $100 \%$; bryophytes (terricolous or aquatic): $30 \%$; lichens (terricolous or aquatic): $5 \%$; algae (terricolous or aquatic): $1 \%$ Environmental data: slope aspect: $15 \%$; slope inclination: $16 \%$; surface cover other than plants (open soil, litter, bare rock etc.): $45 \%$; soil pH: $70 \%$

Performance measure(s): presence/absence only: $0 \%$; cover: $100 \%$; biomass: $5 \%$

Geographic localisation: GPS coordinates (precision $25 \mathrm{~m}$ or less): $10 \%$; point coordinates less precise than GPS, up to $1 \mathrm{~km}$ : $30 \%$; small grid (not coarser than $10 \mathrm{~km}): 20 \%$; political units or only on a coarser scale $(>10 \mathrm{~km}): 40 \%$

Sampling periods: 1930-1939: 1.0\%; 1940-1949: 12.0\%; 1950-1959: 9.0\%; 1960-1969: 2.0\%; 1970-1979: 10.0\%; 1980-1989: 11.0\%; 1990-

1999: 33.0\%; 2000-2009: $21.0 \%$

Information as of 2012-07-17; further details and future updates available from http://www.givd.info/ID/EU-00-006

Table 1: Number of relevés per abiotic parameter in the EC Database; subscripts between brackets indicate the extraction solution (see also Fig. 3), MSW: mean spring groundwater level (GWL), n: number of findings, s.s.: soil surface, MLW: mean lowest GWL, MHW: mean highest GWL, $\mathrm{pH}_{(\mathrm{H} 2 \mathrm{O})} \mathrm{pH}$ in water extract, $\mathrm{pH}_{(\mathrm{KCl})} \mathrm{pH}$ in potassium chloride extract, $\mathrm{pH}_{(\mathrm{CaCl}):} \mathrm{pH}$ in calcium chloride extract, Organic: organic matter content of the soil, $\mathrm{N}_{\text {total }}$ : Total nitrogen content, $\mathrm{NO}_{3(\mathrm{Cac} 12)}$ : nitrate content in calcium chloride extract, $\mathrm{NH}_{4(\mathrm{CaCl2})}$ : ammonium content in calcium chloride extract, $\mathrm{Nts} \mathrm{(CaCl2)}_{2}$ : total of nitrate, ammonium and $\mathrm{N}$-amino acid content in calcium chloride extract, $\mathbf{P}_{\text {total }}$ : total phosphorus content, $\mathbf{P}_{(\text {citric acid) }}$ : $\mathbf{P}$ content after citric acid extraction, $\mathbf{P}_{(\mathrm{Cac} 12)}$ : $\mathbf{P}$ content in calcium chloride extract, $\mathrm{K}_{\text {total }}$ : total potassium content, $\mathrm{K}_{(\mathrm{CaCl})}$ : $\mathrm{K}$ content in calcium chloride extract, $\mathrm{Ca}_{(\mathrm{NaCl})}$ : calcium content in sodium chloride extract, $\mathrm{CaCO}_{3}$ : calcium carbonate content, $\mathrm{Mg}_{(\mathrm{CaCl2})}$ : magnesium content, $\mathrm{Cl}_{(\mathrm{H} 20)}$ : chloride content in water extract, $\mathrm{C} / \mathrm{N}$ : carbon to nitrogen ratio, $\mathrm{CEC}$ : cation exchange capacity.

\begin{tabular}{|c|c|c|c|c|c|c|c|c|c|c|c|c|c|c|c|}
\hline \multicolumn{2}{|l|}{ MSW } & \multicolumn{2}{|l|}{ MLW } & \multicolumn{2}{|l|}{ MHW } & \multicolumn{2}{|c|}{$\mathrm{pH}_{(\mathrm{H} 2 \mathrm{O})}$} & \multicolumn{2}{|l|}{$\mathrm{pH}_{(\mathrm{KCl})}$} & \multicolumn{2}{|l|}{$\mathrm{pH}_{(\mathrm{CaCl} \mid 2)}$} & \multicolumn{2}{|l|}{ Organic } & \multicolumn{2}{|l|}{$\mathrm{N}_{\text {total }}$} \\
\hline cm -s.s. & $n$ & $\mathrm{~cm}$-s.s. & $n$ & cm -s.s. & $n$ & & $n$ & & $n$ & & $n$ & $\%$ & $n$ & $\mathrm{~g} / \mathrm{kg}$ & $n$ \\
\hline$-100--50$ & 12 & $-55-0$ & 65 & $-100--50$ & 8 & $3.0-4.0$ & 446 & $2.0-3.0$ & 99 & $2.5-3.5$ & 157 & $0.0-2.5$ & 516 & $0.010-1$ & 625 \\
\hline$-50-0$ & 156 & $0-50$ & 178 & $-50-0$ & 199 & & 632 & & 641 & & 112 & & & & 765 \\
\hline $0-12.5$ & 144 & $50-100$ & 503 & $0-50$ & 777 & & 62 & -4.5 & 425 & 4.5 & 119 & & & & 512 \\
\hline $12.5-25$ & 223 & $100-150$ & 311 & $50-100$ & 298 & & 89 & -5.0 & 678 & & 91 & & & & 265 \\
\hline $25-50$ & 226 & 0-200 & 454 & $100-150$ & 135 & & 1053 & & 710 & & 64 & & 45 & & 150 \\
\hline $50-75$ & 210 & & 73 & & 231 & & & & 3 & & 32 & & & & 169 \\
\hline $75-100$ & 79 & $300-400$ & 25 & $200-250$ & 22 & & 38 & -6.5 & 202 & & 40 & $30-40$ & 10 & $7.5-10.0$ & 110 \\
\hline $100-150$ & 59 & $400-500$ & 3 & $250-300$ & 7 & $7.0-7.5$ & 473 & $6.5-7.0$ & 268 & $6.5-7.0$ & 58 & $40-50$ & 86 & $10.0-15.0$ & 146 \\
\hline $150-200$ & 57 & $500-600$ & 6 & $300-350$ & 4 & $7.5-$ & 30 & $7.0-7.5$ & 259 & & 130 & $50-75$ & 87 & $5.0-25.0$ & 217 \\
\hline $200-250$ & & $600-8$ & 3 & $350-505$ & & $8.0-9.6$ & 23 & $7.5-9.1$ & 142 & $7.5-8.0$ & 16 & $75-100$ & 36 & $25.0-35.0$ & 18 \\
\hline
\end{tabular}

\begin{tabular}{|c|c|c|c|c|c|c|c|c|c|c|c|c|c|c|c|}
\hline \multicolumn{2}{|c|}{$\begin{array}{l}\mathrm{NO}_{3(\mathrm{CaCl})} \\
\mathrm{mg} / \mathrm{kg}\end{array}$} & \multicolumn{2}{|c|}{$\mathrm{NH}_{4(\mathrm{CaCl} / 2)}$} & \multicolumn{2}{|c|}{$\mathrm{Nts}_{(\mathrm{CaCl} / 2)}$} & \multicolumn{2}{|l|}{$P_{\text {total }}$} & \multicolumn{2}{|l|}{$\mathrm{P}_{\text {(citric acid) }}$} & \multicolumn{2}{|l|}{$\mathrm{P}_{(\mathrm{CaCl} 2)}$} & $\mathrm{K}_{\text {total }}$ & $n$ & \multicolumn{2}{|l|}{$\mathrm{K}_{(\mathrm{CaCl} 2)}$} \\
\hline $0.0-1.0$ & 251 & $0.0-2.5$ & 130 & $0-10$ & 69 & $0-100$ & 347 & $10-100$ & 126 & $0.0-0.5$ & 325 & $15-200$ & 120 & $0-15$ & 155 \\
\hline & 138 & & 344 & & 103 & $100-2$ & 422 & & 200 & & 288 & $200-400$ & 88 & & 182 \\
\hline 2.5 & 197 & & 301 & & 70 & & 32 & & 252 & & 18 & & 3 & & 203 \\
\hline & 206 & & 14 & & 8 & 300 & 38 & & 24 & & 13 & 600 & 122 & $35-$ & 140 \\
\hline 10 & 111 & $10-1$ & 145 & & 93 & 450 & 368 & 400 & 203 & & $14 z^{2}-x-2$ & 800 & 80 & $45-55$ & 118 \\
\hline & 121 & $15-2$ & 110 & & 63 & & $3 s$ & & 25 & & 7 & & & & 136 \\
\hline & 15 & & 47 & & 69 & & 2 & & 16 & & & & & & 80 \\
\hline & 103 & $35-50$ & 34 & & 71 & & 256 & & 16 & & 25 & & & 50 & 83 \\
\hline $150-300$ & 18 & $50-150$ & 48 & $100-200$ & 29 & $1500-3000$ & 184 & 1000 & 164 & $25-50$ & 10 & $6000-10000$ & 85 & $150-300$ & 68 \\
\hline $300-810$ & & $150-350$ & & $200-405$ & 6 & $3000-11000$ & 47 & $1500-3200$ & 77 & 50-115 & f & $10000-20000$ & 69 & $300-600$ & 12 \\
\hline
\end{tabular}




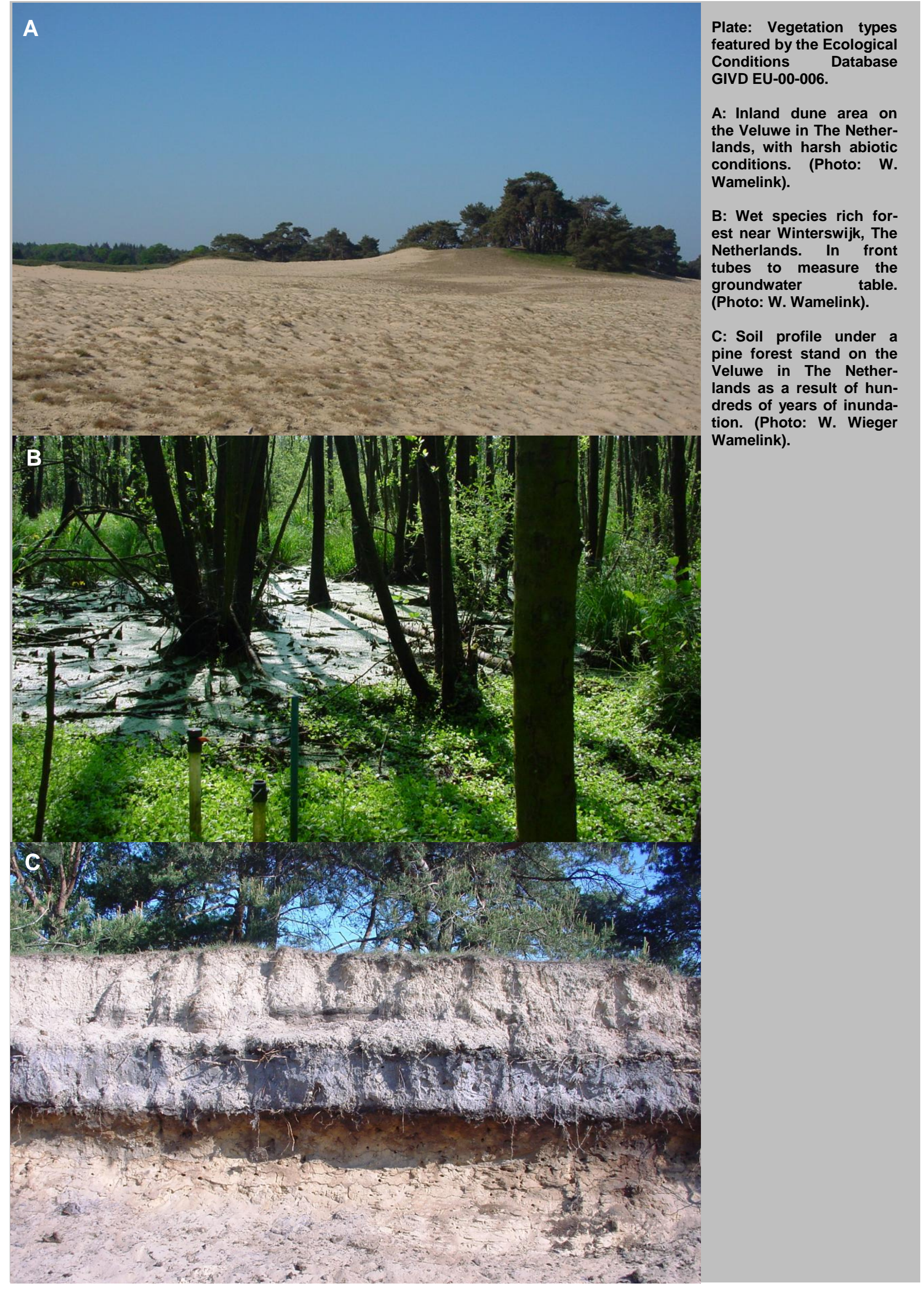


Soil variables, e.g. the $\mathrm{P}$ content of the soil, may significantly vary with the analytical methods used. Therefore, we stored data per detection method, as indicated in Table 1 between brackets. " $\mathrm{P}_{(\mathrm{CaCl} 2)}$ ", for example, indicates that the phosphorus content of the soil was analysed in a calcium chloride extract. Not only differences in analytical methods can give rise to different and incomparable results, sampling techniques in the field can also cause problems. Most influencing is probably the sampling depth, since many soil variables have a gradient over the soil depth. Therefore we only collected data measured in the upper layer of the soil, mostly the top 10 or top $20 \mathrm{~cm}$ below surface. Our own data collection is completely standardised, with soil sampling in the upper $10 \mathrm{~cm}$ and standard storage and analyses. More information can be found in Wamelink et al. (2007) and in the database. More technical information is also given in the Fact Sheet and on the recently launched website of the Global Index of Vegetation-Plot Databases (GIVD; see Dengler et al. 2011) at http://www.givd.info. Several columns are dedicated to the quality control system (see quality control). Information about the original authors is stored on a separate sheet.

The vegetation relevés are grouped by authors and stored in TURBOVEG, a database management system for vegetation data (Hennekens \& Schaminée, 2001). For further processing, the relevés from different authors are combined in Microsoft Access. Soil and vegetation data are linked through relevé ID, which acts as a unique identifier.

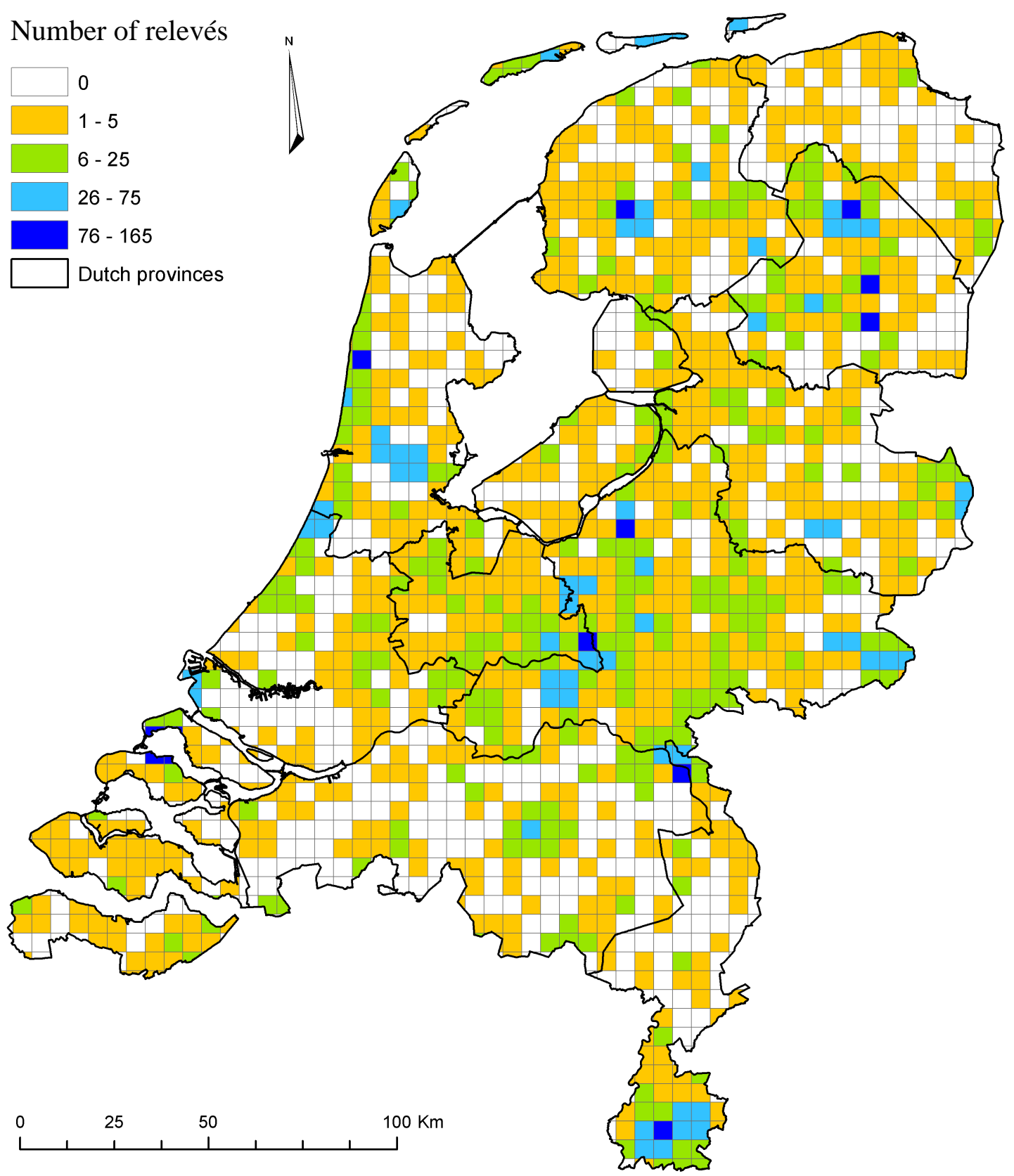

Fig. 1: Map of sample density, number of relevés accompanied by at least one measured soil parameter present in the EC Database per $5 \mathrm{~km} \times 5 \mathrm{~km}$ grid for the Netherlands. 


\section{Content}

Data are collected from throughout the Netherlands, with a strong concentration of records from nature areas (Figs. 1 and 2). Only a small subset of relevés collected along road verges are from outside such nature areas. No data were collected from urban and agricultural areas. Most of the data have been collected for other purposes and therefore the relevés are not randomly distributed over the natural areas but instead reflect the authors' research interests. Some authors have worked nationwide, others in one small area only. Some authors have made numerous relevés, others have made only a few. This is also reflected in the soil analyses: sometimes only one variable has been measured (usually $\mathrm{pH}$ ) and sometimes many (Figs. 3 and 4). This has some disadvantages: the database is not representative for the Dutch vegetation, not even for the Dutch natural areas. Fur- thermore, it is almost impossible to analyse interaction effects, as for any given pair of variables there are only few records where both have been determined. We are currently attempting to fill the gaps in the database, partly by analysing the soil samples taken in the Dutch National Vegetation Monitoring Network (LMF; Van der Peijl et al. 2000, van Dobben \& Wegman 2008).

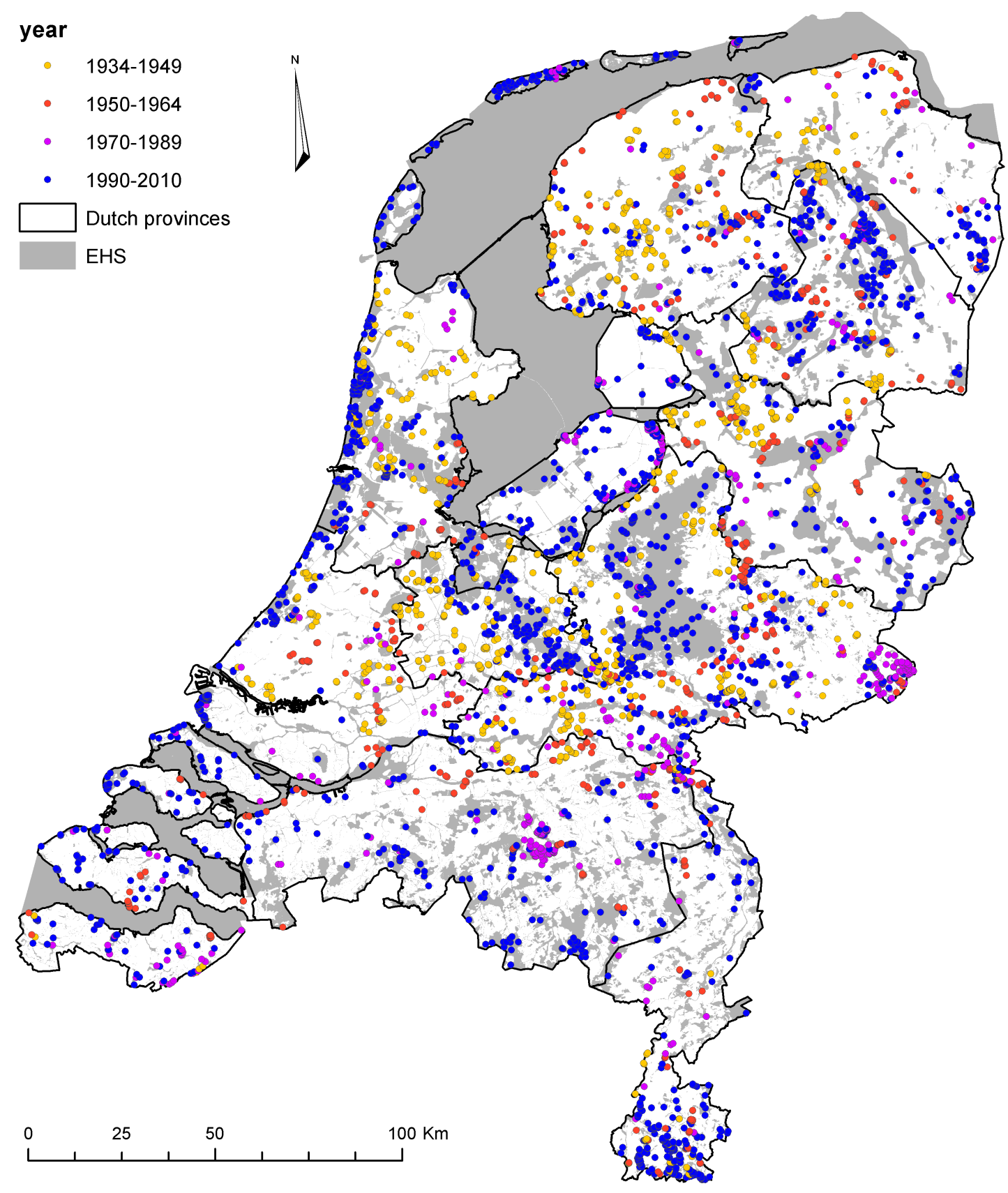

Fig. 2: Map of time period of relevé sampling; grey shading indicates natural areas (EHS = National Ecological Network) in the Netherlands. 


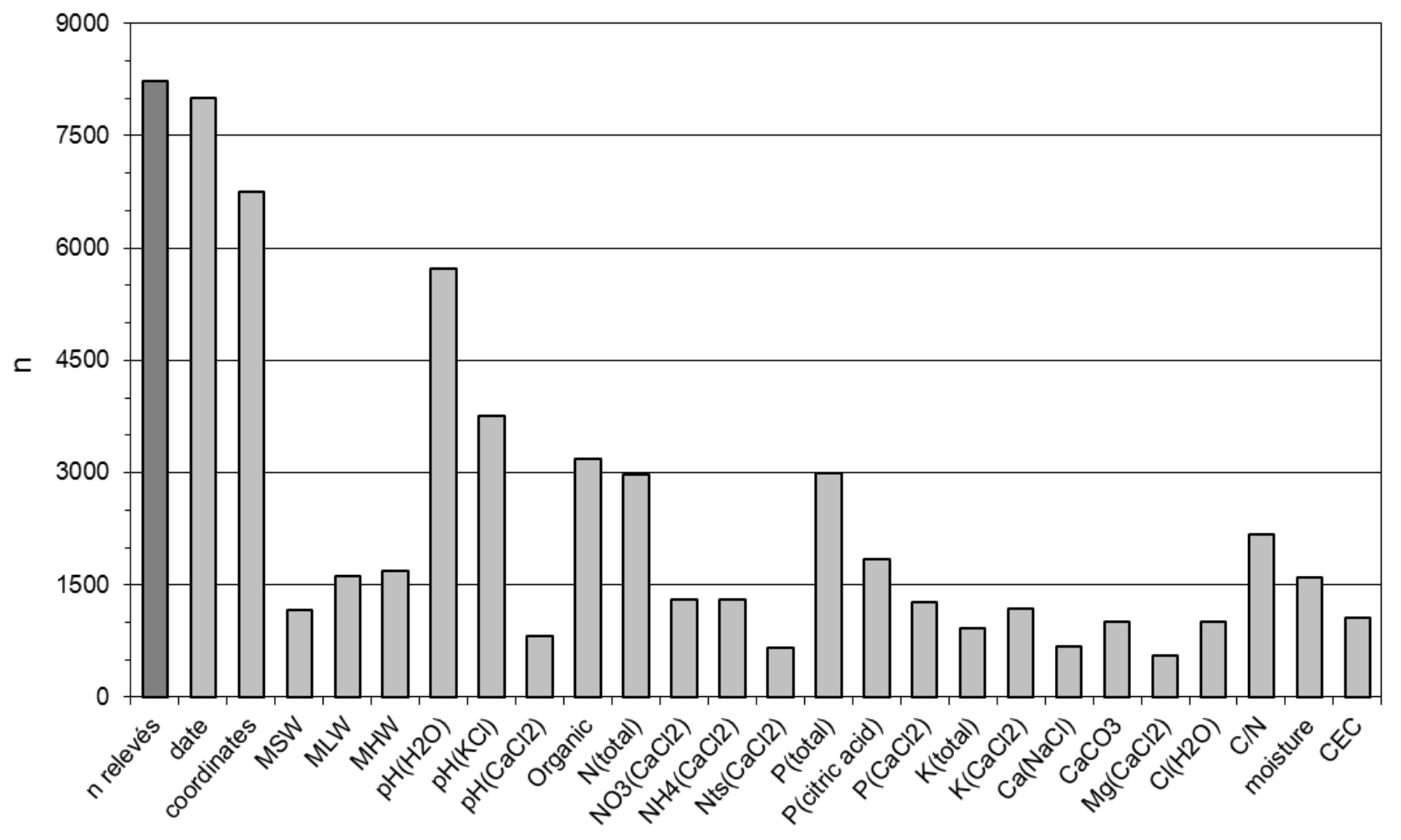

Fig. 3: Number of relevés with measured soil parameters in the EC Database.

\section{Quality control}

Data incorporated in the EC Database are subjected to stringent quality control. After data from a paper or electronic database have been incorporated into the EC Database, the data are checked by an independent person. Whenever possible, data incorporated in digitised form are checked against the original data on paper. Outliers are double-checked, but if no obvious errors are detected they are not discarded. After the data have been checked, a box in the Excel files is ticked. In addition, every data subset is assigned a quality code ranging from $1-4$, which indicates our assessment of its reliability.

The database itself was set up under ISO 9001-2008. This guarantees the reproducible storage of the data, and storage of links to the original data. It also gives guidelines for (internal) scientific quality control of databases and reports by colleagues.

\section{Acknowlegdements}

The paper was written by G.W.W.W., figures and tables were made by M.H.C.v.A., J.Y.F. and R.M.A.W. H.F.v.D. and P.A.S. did a quality check of the manuscript. All authors filled the database and performed quality checks on the data. We are grateful for the comments by one anonymous reviewer. The database comprises data collected by many people. References to the original data can be found on http://www.abiotic.wur.nl. This research was funded by the Department of Science and Knowledge Transfer (DWK) of the Ministry of Agriculture Nature and Food Quality, project number BO-02-011-014. The authors' text editor was J. Burrough.

\section{References}

Chytrý M., Rafajová M. (2003): Czech National Phytosociological Database: basic statistics of the available vegetation-plot data. - Preslia 75: 1-15.

Dengler, J., Jansen, F., Glöckler, F., Peet, R.K., De Cáceres, M., Chytrý, M., Ewald, J., Oldeland, J., Finckh, M., Lopez-Gonzalez, G., Mucina, L., Rodwell, J.S., Schaminée, J.H.J., Spencer, N. (2011): The Global Index of VegetationPlot Databases (GIVD): a new resource for vegetation science. - Journal of Vegetation Science 22: 582-597. CrossRef

Ellenberg. H., Weber, H.E., Düll, R., Wirth, V., Werner, W., Paulißen, D. (1991): Zeigerwerte von Pflanzen in Mitteleuropa (Indicator values for plant species for central Europe). - Scripta Geobotanica 18: 9-166.

Ertsen, A.C.D., Alkemade, J.R.M., Wassen, M.J. (1998). Calibrating Ellenberg indicator values for moisture, acidity, nutrient availability and salinity in the Netherlands. - Plant Ecology 135: 113124. CrossRef

Ewald, J. (2001): Der Beitrag pflanzensoziologischer Datenbanken zur vegetationsökologischen Forschung (Contribution to phytosociological data bases for ecology research). - Berichte der Reinhold-Tüxen-Gesellschaft. 13: 53-69.

Hennekens, S.M., Schaminée, J.H.J. (2001): TURBOVEG, a comprehensive data base management system for vegetation data. - Journal of Vegetation Science 12: 589-591. CrossRef

Mol-Dijkstra J.P.M., Reinds G.J., Kros H., Berg, B., de Vries, W. (2009): Modelling soil carbon sequestration of intensively monitored forest plots in Europe by three different approaches. - Forest Ecology and Management 258: 1780-1793.

Schaffers, A.P., Sýkora, K.V. (2000): Reliability of Ellenberg indicator values for moisture, nitrogen and soil reaction, comparison with field measurements. Journal of Vegetation Science 11: 225244. CrossRef

Schaminée, J.H.J., Hennekens, S.M., Chytry, M., Rodwell, J.S. (2009). Vegetation-plot data and databases in 


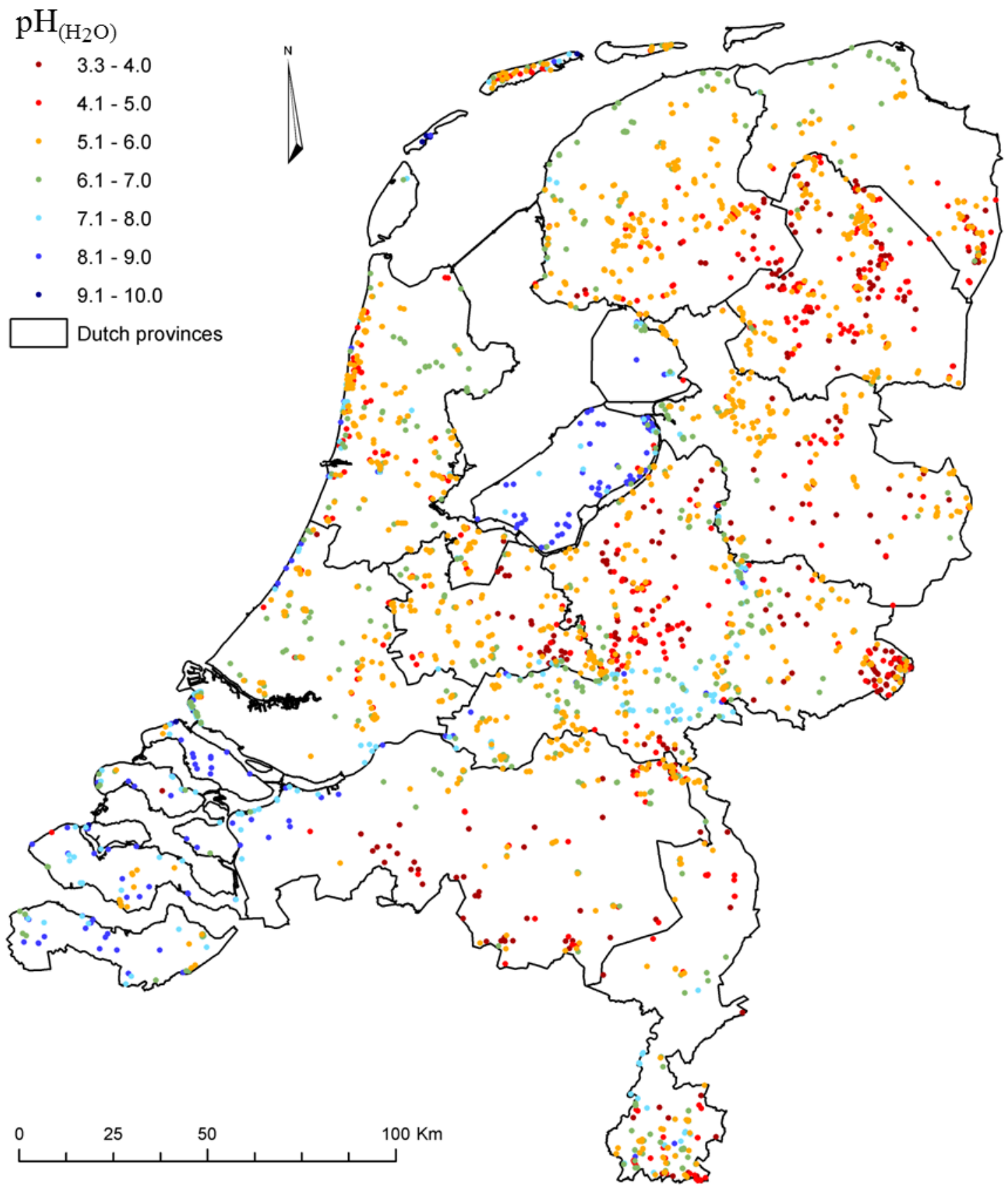

Fig. 4: Map of measured soil pH values present in the EC Database.

Smart S.M., Clarke R.T., van de Poll H.M., Robertson E.J., Shield E.R., Bunce R.G.H., Maskell L.C. (2003): Nationalscale vegetation change across Britain; an analysis of sample-based surveillance data from the Countryside Surveys of 1990 and 1998. - Journal of Environmental Management 67: 239-254. CrossRef

Smart, S.M., Scott, W.A. (2004): Bias in Ellenberg indicator values: problems with detection of the effect of vegetation type. - Journal of Vegetation Science 15: 843-846. CrossRef van der Peijl, M.J., Gremen, N.J.M., van Tongeren, O.F.R., de Heer, M. (2000): Ontwerp Landelijk Meetnet Flora - Milieu \& Natuurkwaliteit (LMF - M\&N) (Design of a nation wide flora inventory network - environmental and nature quality). - RIVM Report $\mathbf{7 1 8 1 0 1 0 0 1 .}$ Bilthoven: RIVM

van Dobben, H.F., Wegman, R.M.A (2008): Relatie tussen bodem, atmosfeer en vegetatie in het Landelijk Meetnet Flora (LMF) (relation between soil, atmosphere and vegetation in the national inventory network flora). - WOT Werkdocument 111. Wageningen: WOT. Wamelink, G.W.W., Joosten, V., van Dobben, H.F., Berendse, F. (2002): Validity of Ellenberg indicator values judged from physico-chemical field measurements. - Journal of Vegetation Science 13: 269-278. CrossRef

Wamelink, G.W.W., van Dobben, H.F. (2003a): Uncertainty of critical loads based on the Ellenberg indicator value for acidity. - Basic and Applied Ecology 4: 515-523. $\underline{\text { CrossRef }}$ 
Wamelink, G. W. W., van Dobben, H. F. Berendse, F. (2003b): Apparently we do need phytosociological classes to calibrate Ellenberg indicator values! - Journal of Vegetation Science 14: 619-620. CrossRef

Wamelink, G.W.W., Goedhart, P.W., van Dobben, H.F. (2004): Measurement errors and regression to the mean cannot explain bias in average Ellenberg indicator values. - Journal of Vegetation Science 15: 847-851. CrossRef

Wamelink, G.W.W, Goedhart, P.W., van Dobben, H.F., Berendse, F. (2005): Plant species as predictors of soil $\mathrm{pH}$ : replacing expert judgment by measurements. - Journal of Vegetation Science 16: 461-470. CrossRef

Wamelink, G.W.W., Goedhart, P.W., Frissel, J.Y., Wegman, R.M.A., Slim,
P.A., van Dobben, H.F. (2007). Response curves for plant species and vegetation types. - Report 1489. Wageningen: Alterra.

Wamelink, G.W.W., van Dobben, H.F., Berendse, F. (2009): Vegetation succession as affected by decreasing nitrogen deposition, soil characteristics and site management: a modelling approach. - Forest Ecology and Management 258: 1762-1773. CrossRef

Witte, J.P.M., von Asmuth, J.R. (2003): Do we really need phytosociological classes to calibrate Ellenberg indicator values? Journal of Vegetation Science 14: 615618. CrossRef
G.W. Wieger Wamelink* (wieger.wamelink@wur.nl), Marjolein H.C. van Adrichem (marjolein.vanadrichem@wur.nl), Han F. van Dobben (han.vandobben@wur.nl), Joep Y. Frissel (joep.frissel@ wur.nl), Merel den Held (merel.denheld@ wur.nl), Veronique Joosten (vero-

peter@kpnplanet.nl), Agnieszka H.

Malinowska (agnieszka.malinowska@wur.nl), Pieter A. Slim (pieter.slim@wur.nl) \& Ruut M.A. Wegman (ruut.wegman@wur.nl) Alterra, Wageningen UR Droevendaalsesteeg 3a, P.O. Box 47 6700 AA Wageningen, NETHERLANDS

*Corresponding author 